\title{
Mokřady na archivních mapových podkladech
}

\section{PAVEL RICHTER}

\author{
Klíčová slova: archivní mapy - mokřady - GIS - zadržení vody v krajině - zemědělské hospodaření
}

\section{SOUHRN}

V tomto článku jsou představeny dobře dostupné archivní mapové podklady, které poskytují přehled o historické lokalizaci mokřadů a zároveň jsou dobře využitelné pro GIS analýzy. Hlavní výzkumnou otázkou je potenciál využitelnosti jednotlivých mapových děl pro identifikaci historických i obnovujících se mokřadů v České republice a následného vyhodnocení hybných sil zániku nebo obnovy mokřadů. V tomto článku je popsána mapa II. vojenského mapování jako nejvhodnější pro primární detekci historických mokřadů. Tato mapa zobrazuje v podstatě věrně stav krajiny v polovině 19. stol. Byla to, mimo jiné, krajina téměř neregulovaných vodních toků. Podrobnější popis krajiny z tohoto období predstavují mapy Stabilního katastru, které byly určeny pro mapování krajiny k daňovým účelům. Jsou však k dispozici pouze jako jednotlivé mapové listy, které je pro využití v GIS nutno georeferencovat. Dalšími vhodnými podklady pro tyto krajinné analýzy jsou historická ortofotomapa z 50. let 20. století, historické letecké měřické snímky z let 1937-2002 a archivní ortofotomapy z let 1998-2017. Na těchto podkladech je zde znázorněna sukcesní obnova mokřadů na zemědělské půdě. Zjištěné informace Ize využít při krajinném plánování s ohledem na obnovu, ochranu a management mokřadů, které mají nezastupitelnou roli při zadržování vody v krajině. Bohužel z běžné krajiny České republiky se mokřady, s výjimkou rybníků, téměř zcela vytratily. V článku jsou také popsány př́činy krajinných změn, které k tomuto stavu vedly.

\section{ÚVOD}

Hlavním cílem výzkumu prezentovaného v tomto článku je představení dostupných archivních mapových podkladů pro lokalizaci mokřadů v České republice. Hlavní výzkumnou otázkou je pak potenciál využitelnosti jednotlivých mapových děl pro identifikaci historických i obnovujících se mokřadů v ČR a následného vyhodnocení hybných sil zániku nebo obnovy mokřadů.

Mokřady predstavují funkční rozhraní mezi suchozemskými ekosystémy a povrchovými vodami. Mají vyrovnávací a filtrační funkci průtoku vody, sedimentů a rozpuštěných živin a znečištujících látek. Jinými slovy zmírňují dopady povodní a sucha v krajině, zlepšují kvalitu vody ve vodních tocích a zmírňují důsledky eroze [1-4].

Mokřady patří také mezi nejúčinnější krajinné prvky pro obnovu krátkého vodního cyklu, který je klíčový pro zadržování vody v krajině. Část živin a dalších látek unášených vodou se zde usazuje a využivá. Tyto látky tedy neodcházejí z povodí, ale recyklují se. Půda se též dosycuje vodou [5].

To jsou vše velmi pozitivní skutečnosti v tzv. boji s klimatickou změnou (spiše tedy ve zmírňování jejích důsledků). Je tu ještě jedna důležitá skutečnost: v mokřadech je vázán uhlík, o jehož neutrální bilanci nyní Evropa usiluje do roku 2050. Schopnost zadržet uhlík se liší podle klimatu, půdních vlastností a typu mokřadu, ale obecně lze říci, že v mírném pásu, kam Česká republika patří, se kumulace uhlíku pohybuje mezi 0,2 a 1,2 tunami ročně na hektar. Množství uhlíku, které je zadržováno v mokřadech poukazuje na jejich významnou roli v globálním koloběhu tohoto prvku. Bylo zjištěno, že export uhlíku z mokřadů je výrazně vyšší v oblastech, které byly odvodněny nebo jinak narušeny [6, 7]. To je aktuální také v podmínkách ČR, protože velké množství mokřadů mírného pásu, které akumulují uhlík v případě, že nejsou narušovány, bylo odvodněno pro potřeby zemědělství a lesnictví. Jedním ze způsobů, jak snížit množství skleníkových plynů, které unikají do atmosféry, je tedy zvýšení obsahu půdní organické hmoty, která se ve velké míře vyskytuje zejména v mokřadech.

\section{DEFINICE MOKŘADU゚}

Mokřady jsou velmi variabilní biotopy a jejich definice je poměrně obtížná, všechny však mají společné základní rysy. Pro mokřady je typická př́tomnost vody bud' v nasyceném půdním profilu, nebo v mělké vodě. Je to stále, či jen po určité období roku, zatopené území nebo území s půdou, která je soustavně nasycená podzemní vodou. Představují prolínání terestrického a vodního prostředí. Mokřady jsou složeny ze tři základních komponentů, týkajících se hydrologie, bioty a fyzikálně-chemického prostředí, které jsou ovlivňovány klimatickými a geomorfologickými podmínkami (obr. 1).

Podle Mitsche a Gosselinga [8] Ize důvody nejednoznačnosti definování mokřadů shrnout do následujících bodů:

— voda je v mokřadech prítomna po většinu roku, ale její množ-

ství se může v průběhu roku nebo i několika let značně lišit; některé mokřady jsou zaplaveny kontinuálně, jiné pouze sezonně,

— mokřady jsou jistým prodloužením terestrického a vodního ekosystému, zároveň nesou znaky obou a nemají identitu vodních ani suchých stanovišt',

- mokřadní druhy rostlin a živočichů mohou být adaptovány na ekologické podmínky mokřadů fakultativně (druhy vyhledávají mokřady) nebo obligátně (druhy mohou existovat pouze na mokřadu nebo jeho typu, jsou to indikátory mokřadů),

- různorodost mokřadů a nesnadnost jejich definice se projevuje také v jejich rozloze; mokřady mohou mít pouze několik málo ha nebo i m², ale mohou také zabírat obrovské plochy,

— velikost mokřadů je velice důležitá zejména pro jejich ochranu a management; různorodé je i rozmístění mokřadů v různých typech krajin,

— stav mokřadů nebo stupeň jejich antropogenního ovlivnění se liší v rámci států, jednotlivých regionů nebo v rámci různých typů mokřadů; odlišné problémy se objevují v krajině zemědělské, industrializované nebo urbanizované.

V Ramsarské úmluvě o mokřadech [9] se mokřady rozumí území s močály, slatinami, rašeliništi a vodami prirozenými nebo umělými, trvalými nebo dočasnými, stojatými i tekoucími, sladkými, brakickými nebo slanými, včetně území s mořskou vodou, jejíž hloubka při odlivu nepřesahuje šest metrů. 


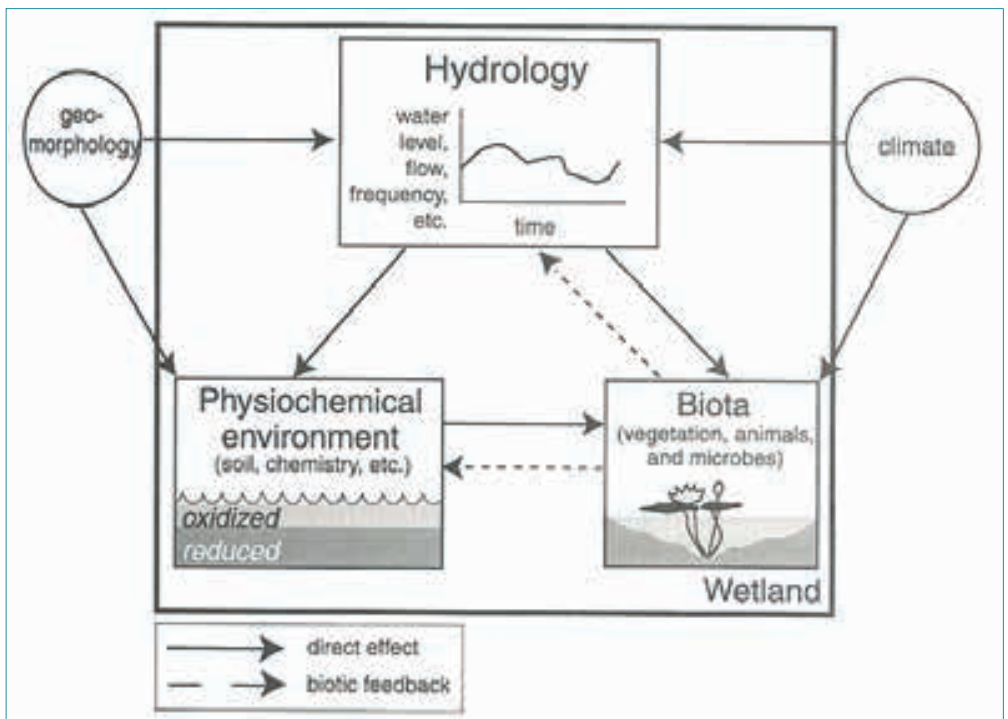

Obr. 1. Základní komponenty mokřadů [8]

Fig. 1. Basic components of wetlands [8]

V podmínkách České republiky jsou k mokřadům raazeny zejména rybníky a jejich litorály, zaplavované nebo mokré louky a prameniště, tůně, rákosiny, ostřicové louky, ríční nivy včetně lužních lesů, rašeliniště, podmáčené smrčiny, zatopené lomy, štěrkovny, pískovny a také mokřady umělé - kořenové čistírny odpadních vod.

\section{HISTORICKÉ SOUVISLOSTI A SOUČASNÝ STAV KRAJINY}

Již od samých počátků existence lidské civilizace člověk přetváří, at již vědomě nebo nevědomě, své životní prostředí. S následky této činnosti se príroda vyrovnávala bez větších potiží a bez trvalého negativního vlivu na fungování ekosystémů. Teprve s přibývajícím počtem lidí a přechodem na zemědělské využívání krajiny docházelo k vytváření nových ekosystémů, více či méně ovlivněné člověkem, avšak bez podstatného narušení prírodní rovnováhy. Výraznější problémy nastávají teprve s prudkým nárůstem počtu jedinců v lidské populaci. Zemědělci nikdy nevytvářeli krajinu na základě svých estetických záměrů, ale krajina byla vedlejším produktem jejich hospodaření. Vždy bojovali s prírodou, jejich základní starostí bylo uživit vlastní rodiny a uspokojit požadavky vlastníků půdy. Avšak zkušenost je naučila např. udržovat meze, chránit pole a krajinu před erozí a udržovat v přiměřeném rozsahu lesy. Postoje zemědělců k prírodě jako k něčemu, s čím se musí bojovat, přetrvávaly i v pozdější době, kdy byly výnosy z polí mnohem vyšší, a nemuseli mít takové obavy o uživení rodiny. Přestože prírodu omezovali a snažili se ji co nejvíce eliminovat, nebyli až do určité doby, schopni dosáhnout dlouhodobějšího vítězství, protože jejich technologická vyspělost nebyla dostačující [10]. Krajinné prvky jako jsou keře, pestré porosty mezí a luk, společenstva drobných mokřadů aj., označované jako krásné a ekologicky cenné, jsou v podstatě drobnými úspěchy prírody, na které bylo lidské snažení krátké [11]. Výrazné stopy zanechalo v krajině pưsobení mocenských elit v letech 1948-1989. K nejpatrnějším trvalým krajinným zásahům patřila kolektivizace zemědělství. Rozoráváním mezí, rušením mnoha polních cest a scelováním polí a luk vznikaly pozemky s mnohonásobně větší rozlohou [12]. V 60. a 70. letech minulého století došlo vlivem meliorací, regulací drobných vodních toků a vysušováním mokřadů k výraznému snížení vodních a mokřadních ploch. Trendem bylo postupné zvětšování výměry pozemků zemědělské půdy a postupná likvidace zemědělských usedlostí ve prospěch kolektivních socialistických podniků $[13,14]$. Tlak na rozšiřování výměry orné půdy se zvyšoval i v 80. letech minulého století. Došlo k úbytku trvalých travních porostů, rozorávání a odvodnění luk v údolních nivách, likvidaci stabilizačních prvků $v$ zemědělské krajině. Struktura naši krajiny se výrazně zjednodušila [15]. Touto činností člověk urychlil cyklus vody, ta nyní odtéká rychle přes drobné vodoteče anebo prímo do velkých řek a odtud do moří a vrací se zpět až v podobě frontálních srážek. Období mezi velkými srážkami jsou suchá, extrémně vysoké teploty a malá vlhkost poškozují trvalou vegetaci. Voda v krajině již takřka neobíhá v koloběhu výparu a místních srážek (krátký vodní cyklus) [5]. Mezi hlavní prǐ́činy utlumení krátkého vodního cyklu patří nízká sorpční schopnost půdy, utužení půdy a likvidace trvalých porostů (lesních i bylinných) s vysokou kapacitou vázat vodu [16]. Současným způsobem hospodaření je krajina vysoušena, v důsledku čehož byl v podstatě krátký cyklus vody zrušen a bylo tak znemožněno utváření mírného místního klimatu [5].

Bohužel, od 90. let minulého století společnost promarnila jedinečnou šanci ke změně a započaté trendy pokračují, což se silně negativně nyní projevuje jak v zemědělství, tak v lesnictví v souvislosti s dlouhodobým suchem. Bylo by zapotřebí v krajině na vhodných lokalitách neprodleně začít budovat a obnovovat vodozádržné prvky. Pro krajinné plánování je potřebné hledat inspiraci ve starých mapách. Ty jsou vhodné jako podklad k obnově prameništ, rybníků, mokřadů nebo alejí [17]. Pro vytváření podkladů pro krajinnou obnovu lze využít historických leteckých snímků a map stabilního katastru s ohledem na přiblížení stavu krajiny její podobě před scelováním pozemků v rámci kolektivizace zemědělství. Současná společnost stále ještě vnímá zemědělské hospodaření jako primární činnost v krajině, bez ohledu na další krajinné funkce, jež jsou značně potlačovány. Lidé si neuvědomují, že způsob hospodaření, distribuce kultur a přirozené vegetace se projevují v krajině zřetelnými rozdíly $v$ disipaci sluneční energie, v dynamice vodního režimu a v kvalitě povrchové i podzemní vody. Zemědělské hospodaření v krajině totiž určuje hlavní toky energie a látek, které jsou hlavními faktory pro celkové fungování krajinných celků [18]. Jednou z prričin současného stavu české krajiny je skutečnost, že sedlák, pro kterého péče o půdu a krajinu byla přirozená, byl nahrazen zemědělcem, na nějž musí dohlížet úředník. Krajina odpovědných vlastníků a hospodářủ byla za posledních šedesát let transformována v krajinu alibistů a byrokratů. Vlastnictví půdy je $v$ současnosti natolik rozdrobené, že se vlastníkem krajiny necítí $\vee$ podstatě nikdo. Většina půdy v této zemi patři soukromým vlastníkům. Stát, který vlastníkům půdu znemožnil uživat po dlouhých více než čtyřicet let, ji neodevzdal v nejlepším stavu. Vlastníci většinou své pozemky propachtují velké zemědělské společnosti. Ta na nich chce hlavně vydělávat a ne se o ně starat, protože nejsou v jejím vlastnictví [19]. Vztah společnosti ke krajině zřejmě nezávisí jen na historických souvislostech, které k tomuto stavu vedly. Obdobný stav krajiny jako v ČR obecně je v povodí Mississippi v USA. Došlo ke zmenšení mocnosti ornice v oblasti na polovinu. Přičítá se to tomu, že farmáři si pronajímají půdu na krátkou dobu a v důsledku toho se obvykle nestarají o budoucnost. Když je ornice degradována, prostě jdou dále. Skutečnému vlastníkovi se těžko soupeři s někým, komu nezáleží na dlouhodobé perspektivě [20]. Jedním z nejdůležitějších vodozádržných prvků v krajině jsou mokřady. Mají mj. velkou schopnost zadržovat vodu v období nadměrných srážek a v období sucha ji pak postupně uvolňovat [8], tzn. že v krajině působí z hlediska vody jako jakási houba. Lokalizace a struktura mokřadů se v čase mění, stejně jako se mění krajina vlivem působení prírodních, ale hlavně antropogenních faktorů. $V$ minulosti lidé na území současné ČR využívali mokřadní biotopy pro svưj prospěch, aniž by je tím ohrožovali nebo do nich nevhodně zasahovali. Pravidelně kosili mokřadní louky a sekali rákos. Pomocí melioračních př́kopů zároveň udržovali optimální vlhkost přírodních mokřadů [21]. V dnešní době se, až na výjimky, většinou ze strany Správy $\mathrm{CHKO}$, nic podobného neděje. Z naší krajiny mokřady, nepočítáme-li rybníky a některé lokality ve zvláště chráněných územích, takřka vymizely. Krajina $v$ minulosti byla $v$ mnoha ohledech lépe funkční (ekologicky, prakticky, z hlediska hospodářského nebo protierozní ochrany atd.) než $v$ současnosti. 
Koncem června 2020 prožíváme nepřetržitě od roku 2014 již sedmý suchý rok, což se po ničivé povodni v roce 2013 jeví víceméně jako paradox. Nicméně ve druhé červnové dekádě roku 2020 přišla výraznější srážková činnost, která měla za následek rychlý nástup povodňového stavu, zejména v povodí Odry ale také v povodí Labe v Královéhradeckém a Pardubickém kraji. Největší problémy byly na drobných vodních tocích, které se již vylévaly z koryt, zatímco vodní nádrže byly převážně na úrovni zásobních hladin a jejich retenční prostory pro zachycení povodně byly vyprázdněné. Namísto dosycení krajiny vodou a zlepšení stavu vzniklého $v$ důsledku dlouhotrvajícího sucha přinesla intenzivnější srážková činnost do krajiny povodeň. Obdobná situace byla na přelomu května a června 2013 ve východní části Středočeského kraje v povodí Labe a Vltavy, kde rozvodněné drobné vodní toky nakonec zapríčinily ničivou povodeň mj. v Praze, kde se mezi zaplavenými oblastmi ocitl také areál VúV TGM, v. v. i. Z výše uvedeného textu vyplývá, že záplavy a sucha jsou dvě strany jedné mince, která je odrazem způsobu hospodaření v krajině. Jedním z nejzávažnějších negativních dopadů právě probíhající klimatické změny je vliv na vodní režim a vodní zdroje v krajině. Dochází k přesunu nejintenzivnějších srážek do letních měsíců, kdy panují nejvyšší teploty. V rámci celkové vodní bilance tak rostou ztráty evapotranspirací, př́valové deště zrychlují povrchový odtok a omezují schopnost infiltrace srážkové vody. V období nejvyšší spotřeby vody pro průmysl, zemědělství i domácnosti tak klesá disponibilní objem vody.

Nyní jsme také zaplaveni zprávami o kưrovcové kalamitě, na vině však není kůrovec, ale člověk se svým zaslepeným opakovaným masovým vysazováním smrkových monokultur na nepưvodních stanovištích. Usychají dokonce již i borové lesy. Na vytěžených místech vzniknou paseky a ty budou mít vliv na vyšší vysušování krajiny. Stejně tak trpí suchem i zemědělci, zřejmě bude opět menši úroda a oni budou žádat finanční kompenzace za škody způsobené suchem. Ale pravda je taková, že škody nezpưsobuje primárně sucho, ale právě ti zemědělci, kteří svým způsobem hospodaření opět vysušují krajinu. Řešením by bylo namísto současného způsobu vyplácení dotací na zemědělskou činnost v krajině (zacílené víceméně pouze na kvantitu nikoli kvalitu) a kompenzací za neúrodu zacílit tyto finanční prostředky na správný způsob hospodaření a obnovu a vytváření vodozádržných prvků v krajině. K tomu je zapotřebí znát historický stav naší krajiny, kdy lidé ještě neměli prostředky na to, aby krajinu ve velké míre přetvářeli a nezbylo jim pro přežití nic jiného, než žít s ní v souladu. Jinými slovy, nežili podle hesla "Poručíme větru, dešti", ale spíše „Porozumíme větru, dešti a přizpůsobíme tomu své hospodaření v krajině". Naši předci neměli žádné dotace a tak se museli rídit selským rozumem pro to, aby přežili a mohli v zachovalé funkční krajině hospodařit oni i jejich potomci. Obnova mokřadů, remízků, drobných vodních nádrží, revitalizace drobných vodních toků a zatravňování údolnic spolu s návratem k tradičnímu obdělávání půdy jsou střípky do mozaiky ke zlepšení stavu naší krajiny pro zadržování vody v krajině. Tou naopak není navrhování nových vodních nádrží bez souvisejících opatření v krajině. Při návrhu těchto nádrží se zřejmě nebere v úvahu evapotranspirace, při které se při současné klimatické situaci ročně může uvolnit do atmosféry takřka takové množství vody rovnající se objemu zadržení vody v zásobních prostorech jednotlivých nádrží. Jinými slovy, využití těchto nádrží by bylo v současné krajině spíše vhodné pro zadržení prívalových srážek a následnému časově omezenému nadlepšování průtoků.

Nikoli však pro zažitý způsob hospodaření, kdy ve stávajících nádržích vlivem současných klimatických podmínek ubývá voda a obvyklým jevem je naplnění zásobního prostoru nádrže pouze ze tř́ čtvrtin. Následným problémem je také eutrofizace takto "naplněných" nádrží. Jak ukázala mj. povodňová situace z roku 2013 i nejnovější z června 2020, výstavba nových nádrží určitě nevyřeší problém soustředěného odtoku z polí a rychlého vzestupu hladin v drobných vodních tocích, které jsou téměř všechny napřímené a nemají žádný prostor pro přirozený rozliv do krajiny mimo zástavbu.

\section{ARCHIVNÍ MAPOVÉ PODKLADY}

Niže je stručný přehled archivních mapových podkladů, které jsou dobře dostupné a využitelné pro získání přehledu o historické lokalizaci mokřadů a zároveň jsou dobře využitelné pro GIS analýzy.

— Stabilní katastr (mapováno 1824-1836 Morava/1826-1843 Čechy): Jednotlivé mapové listy, pro využití v GIS nutno georeferencovat, prohlížení a objednání je možné na webu Archivní mapy Ústředního archivu zeměměřictví a katastru [22]. Měŕitko 1:2 880, resp. 1: 5760 v horských oblastech. Některá území v České republice jsou již georeferencována a prezentována na výše uvedených stránkách jako Císařské otisky SK spojené ve formě bezešvé mapové vrstvy. Jedná se o Moravskoslezský kraj, Hlavní město Prahu, část střední Moravy, východních Čech a jižní Moravy zpracovanou kolektivem výzkumníků z Centra dopravního výzkumu. V průběhu roku 2020 by mělo být zprístupněno území celého Jihomoravského kraje zpracované ve veřejné zakázce kraje soukromým subjektem ve spolupráci s odborníky z Centra dopravního výzkumu a Výzkumného ústavu Silva Taroucy pro krajinu a okrasné zahradnictví, v. v. i.

— II. vojenské mapování (mapováno 1836-1852): Pro prohlížení dostupné na Národním geoportálu INSPIRE [23], zároveň také jako WMS služba [24]. Měřítko 1: 28 800. Toto mapování je širší veřejnosti prístupné také na mapovém portálu Mapy.cz jako mapa z 19. století [25] a také je zveřejněné spolu s velkým množstvím starých topografických map z téměř celé Evropy na mapovém portálu Maps of Europe [26].

- Ortofotomapa 50. léta 20. století: Pro prohlížení dostupná na Národním geoportálu INSPIRE [23]. Není dostupná jako WMS služba. Pro použití v GIS je možno ji zakoupit na základě licenční smlouvy. Taktéž jsou ortofotosnímky z tohoto období k dispozici pro prohližení na stránkách Národního archivu leteckých měřických snímků ČúZK [27] jako položka historická ortofotomapa.

— Historické letecké měřické snímky (LMS) (snímkováno 1937-2002): Jednotlivé snímky, pro využití v GIS nutno georeferencovat, zjištění dostupnosti a objednání je možné na webu Geografické služby AČR [28]. Náhled dostupnosti těchto snímků je možný také na již zmíněném Národním archivu leteckých měřických snímků ČÚZK [27] výběrem území nebo kliknutím do plochy mapy, odkud je uživatel v případě zájmu o konkrétní snímky odkázán na výše zmíněné stránky Geografické služby AČR [28].

— Ortofotomapy (současná, aktuálně 2018/2019 a archivní, snímkováno 1998-2017): Pro prohlížení a zároveň jako WMS služba dostupné na Geoportálu ČÚZK [29, 30], většinou jen část území, podle etap snímkování v ČR.

\section{IDENTIFIKACE MOKŘADU゚ NA ARCHIVNÍCH MAPOVÝCH PODKLADECH}

Nejstarším využitelným mapovým podkladem zobrazením mokřadů jsou mapy stabilního katastru, přesněji řečeno Císařské otisky stabilního katastru. Je na nich zaznamenán historický stav krajiny z poloviny 19. století. Mapy byly vyhotoveny v měrítku 1:2 880, resp. 1: 5760 v horských oblastech. Originální mapy byly pořizovány $v$ terénu a zachycují skutečný stav krajiny před rozmachem průmyslové revoluce. Obsahují také informace o směru proudění vody v tocích a o umístění a tvaru hrází vodních nádrží. V legendě jsou čtyři základní zobrazení mokřadů: močály, močály s rákosovým porostem, mokré louky a rašeliniště (obr. 2). Jsou zde zobrazeny samozřejmě také rybníky, které z definice patří mezi mokřady, ale zároveň jsou nejčastěji pririrazovány k vodním plochám. Mapování stabilního katastru probíhalo 20 let a tak docházelo k různým odchylkám od predepsané legendy, nicméně téměř ve všech obdobích se vyskytují kromě základního zobrazení mokrých luk také mokré louky s dřevinami. Převážně se jedná o symbol listnatých stromů, stejný jako u zobrazení listnatých lesů. Také existují mapové listy se symbolem ovocných stromů na podkladě mokrých 

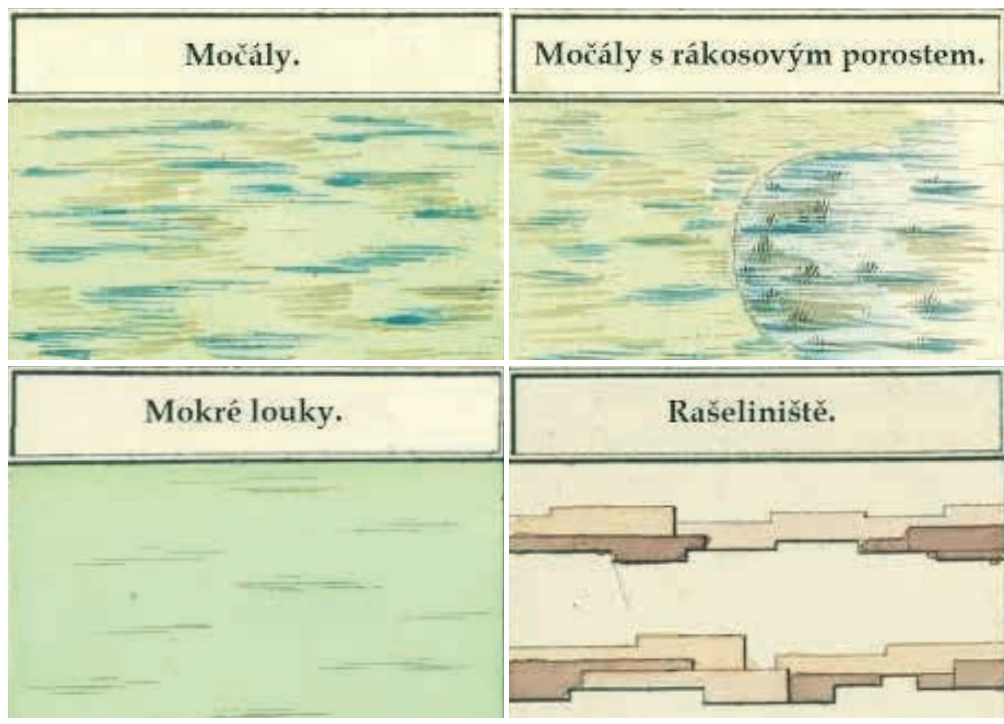

Obr. 2. Zobrazení mokřadů (vyjma rybníků) v legendě Císařských otisků stabilního katastru [22]

Fig. 2. Image of wetlands (excluding ponds) in the legend of the Imperial Imprints of the Stable Cadastre [22]
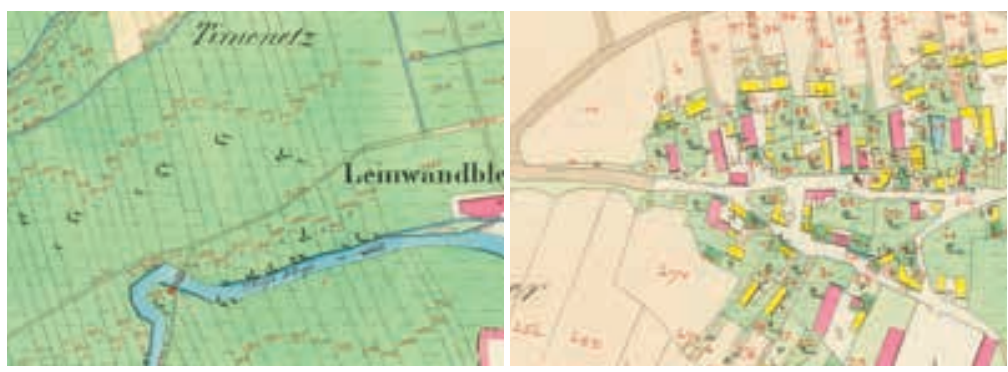

Obr. 3. Mokré louky s listnatými (vlevo) a ovocnými (vpravo uprostřed) dřevinami na Císařských otiscích stabilního katastru [22]

Fig. 3. Wet meadows with deciduous (left) and fruit (middle right) woody plants in the Imperial Imprints of the Stable Cadastre [22]
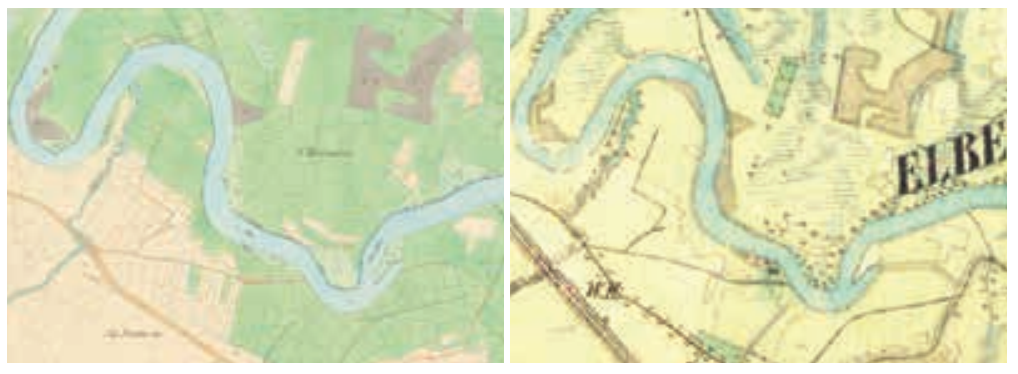

Obr. 4. Porovnání zobrazení mokřadů v Polabí na Císařských otiscích stabilního katastru (1841) [22] a na mapě II. vojenského mapování (1836-1852) [23, 24]

Fig. 4. Comparison of the Elbe river basin wetlands in the Imperial Imprints of the

Stable Cadastre (1841) [22] and on Map II. Military Mapping (1836-1852) [23, 24]

luk, obdobně jako na zobrazení ovocných zahrad a polí nebo luk s ovocnými stromy (obr. 3).

Mapové listy Císařských otisků Stabilního katastru se musí pro použití v GIS georeferencovat. Pro výběr území je vhodné nejprve využít mapu II. vojenského mapování, která je k dispozici pro připojení pomocí WMS služby. Zjednodušeně řečeno se jedná o generalizované zobrazení ze stejného období jako stabilní katastr, jen zaktualizované, takže jsou zde již zaznamenány první železniční tratě. Jednotlivé mapové listy se občas liší barevným provedením.
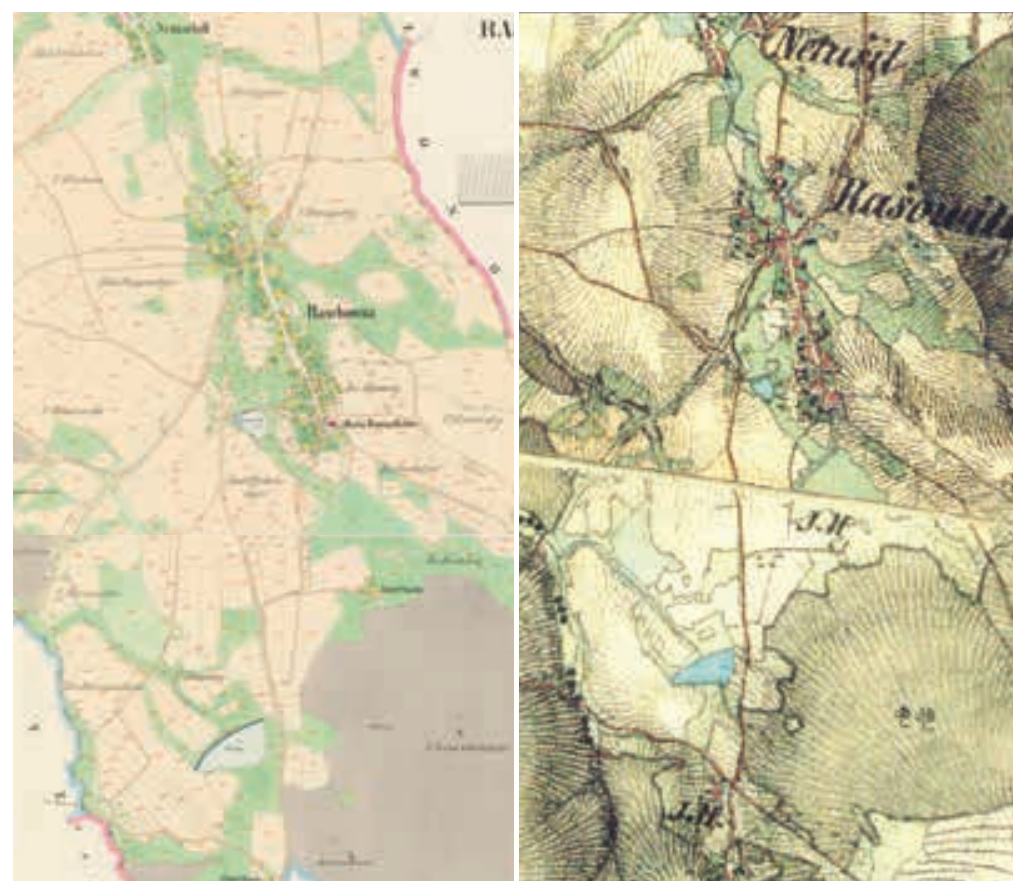

Obr. 5. Porovnání zobrazení mokrých luk v k. ú. Rašovice u Uhlírských Janovic na Císařských otiscích stabilního katastru (1838) [22] a na mapě II. vojenského mapování (1836-1852) [23, 24]

Fig. 5. Comparison wet meadows in cadastral area of Rašovice u Uhlírských Janovic in the Imperial Imprints of the Stable Cadastre (1841) [22] and on Map II. Military Mapping (1836-1852) [23,24]

Na obr. 4 a 5 je porovnání zobrazení mokřadů na Císařských otiscích stabilního katastru a na mapě II. vojenského mapování. Zobrazení mokřadů v Polabí je zde na mapě II. vojenského mapování dobře patrné. V běžné krajině (zde k. ú. Rašovice u Uhliřských Janovic) je na mapě II. vojenského mapování také dobře patrné téměř totožné zobrazení mokrých a suchých luk. Pro indikaci, zda se ve zvoleném území nacházely trvalé travní porosty, je toto zobrazení postačující. Detailní rozdělení je možné až podle Císařských otiscích stabilního katastru. Zobrazení mokřadů na ortofotomapách a historických LMS samozřejmě není samo o sobě úplně jednoznačné ale v návaznosti na historickou lokalizaci mokřadů na Císařských otiscích stabilního katastru a ověření současného stavu terénním průzkumem je prokazatelné.

\section{VYUŽITÍ ARCHIVNÍCH MAPOVÝCH PODKLADŮ PRO ANALÝZU HISTORICKÉHO VÝVOJE MOKŘADU゚}

Pro primární detekci výskytu mokřadů, potažmo TTP na současné zemědělské půdě je nejvhodnější mapa Il. vojenského mapování, zpracovaná v měřítku $1: 28$ 800. Na obr. 6 je vlevo prezentována lokalita v k. ú. Drahlín (podrobněji analyzovaná na obr. 7) a vpravo lokalita v k. ú. Rašovice u Uhlírských Janovic (podrobněji analyzovaná na obr. 8). V horní části jsou obě území znázorněna na mapě II. vojenského mapování, v dolní části pak na současné ZM 10 . Z těchto podkladů je patrné, že mokřadní lokality v krajině byly dosti stabilní a jsou na mapě II. vojenského mapování zretetelně zaznamenány. Na současné ZM 10 je $v$ těchto místech zobrazena jen orná půda, ačkoli současná ortofotomapa zobrazuje $v$ obou lokalitách mokřadní biotop (obr. 7 a 8). Tento stav byl potvrzen terénními průzkumy. Současná ZM 10 dobře zobrazuje pomocí souřadnic svažitost obou pozemků. 


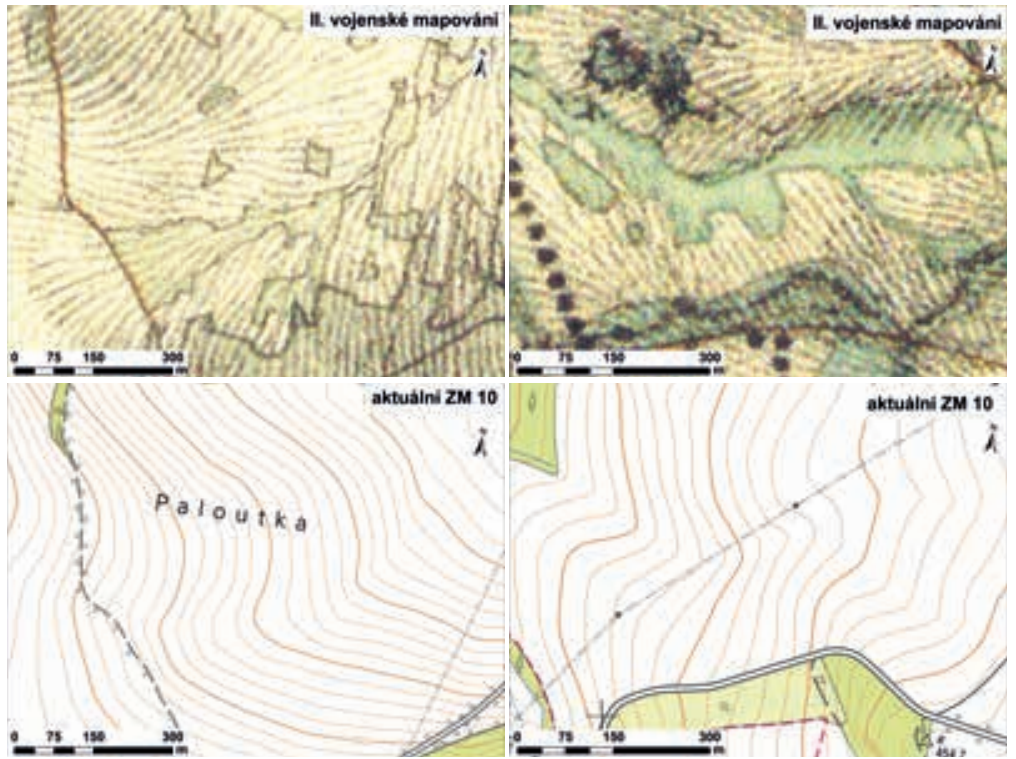

Obr. 6. Porovnání zobrazení historických mokrých luk a současných zamokřených lokalit v k. ú. Drahlín a v k. ú. Rašovice u Uhlířských Janovic na podkladech II. vojenského mapování (1836-1852) [24] a současné ZM 10 [29]

Fig. 6. Comparison of historic wet meadows with current wet localities in cadastral area of Drahlín and in cadastral area of Rašovice u Uhlírských Janovic on Map II. Military Mapping (1836-1852) [24] along with the current base map 1: 10000 [29]

Na obr. 7 je na archivních mapových podkladech prezentován vývoj zemědělské krajiny a mokřadních ekosystémů nacházející se v k. ú. Drahlín (okres Príbram). Použity jsou Císařské otisky stabilního katastru, ortofotomapa z 50. let 20. století, archivní ortofotomapy z let 2005, 2011 a 2015 a současná ortofotomapa. Je zde patrná zachovalá historická lokalizace mokrých luk i v roce 1953. V letech 2005-2019 jsou v této lokalitě pouze dva větší mokřady, které odolávají disturbanci zemědělskou technikou, jsou zde také dobře viditelné stopy vodní eroze. Je také dobře patrný ústup lesa z původní lokality z roku 1839 a jeho nahrazení ornou půdou. $V$ dalších letech je les zřetelný jen $v$ pravém dolním rohu snímků.

Na obr. 8 je podrobněji prezentována lokalita nacházející se v k. ú. Rašovice u Uhlírských Janovic (okres Kutná Hora), kde se vyvijí (obnovuje) mokřadní ekosystém, který je v současnosti pramennou oblastí. Nicméně, současný stav není výsledkem cíleného managementu ale pouze odrazem aktuálního stavu půdy, která neumožňuje obdělávání. Použity jsou stejné podklady, jako u předchozí lokality, jen je navíc zobrazen stav krajiny na LMS z roku 1981. Historické ortofotomapy zobrazuji širší časové období v rozsahu let 2000-2017. Z použitých podkladů je zřejmé, že nejpozději od roku 2008 začíná trend v rozrůstání této lokality vlivem sukcese na okolní zemědělskou půdu. Z mapových podkladů z roku 1838 plyne, že vznikající ekosystém se velkou přesností približuje tvaru a lokalizaci bývalých mokrých luk $v$ této oblasti. Tato skutečnost je potvrzena také leteckým snímkem z roku 1954. Z archivních ortofotomap je zřejmé, že v letech 2005 až 2008 byla na této lokalitě pouze orná půda. Nicméně na snímku z roku 2005 je v lokalitě, na níž se v současnosti nachází mokřad, patrná erozní rýha a v roce 2008 pak rozsáhlejší podmáčená oblast. V roce 2010 pokračoval trend rozrůstání mokřadu do okolí. V roce 2013 (povodňový rok) je patrné rozšírení zamokřené oblasti, v letech 2017-2019 se podmáčená oblast lehce zmenšila, nicméně celkově situace poukazuje na stávající trend rozrůstání mokřadu do okolí. Obě lokality v současnosti nejsou predmětem žádné územní ochrany a podle evidence v katastru nemovitostí je zde pouze orná půda.

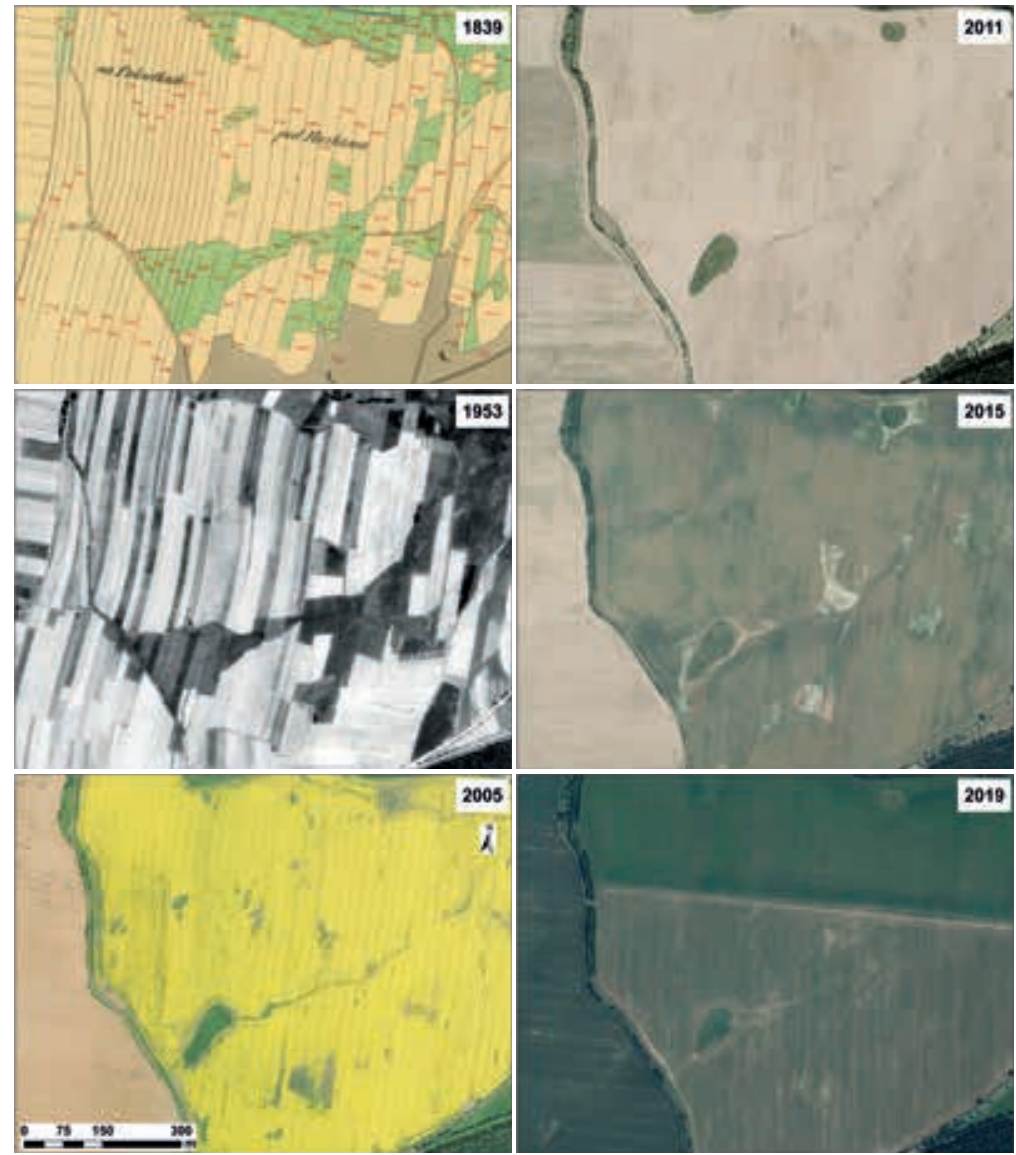

Obr.7. Historický vývoj zamokřené lokality v k. ú. Drahlín na podkladech Císařských otisků stabilního katastru (1839) [22], ortofotomapě z 50. let 20. stol. [24], archivních ortofotomapách (2005-2015) a současné ortofotomapě (2019) [29]

Fig. 7. Historical development of the wet localities in cadastral area of Drahlín in the Imperial Imprints of the Stable Cadastre (1839) [22], orthophotomap from the 1950's [24], archival orthophotomaps (2005-2015) and current orthophotomap (2019) [29]

\section{DISKUSE}

V tomto článku je označena mapa II. vojenského mapování jako nejvhodnějši pro primární detekci mokřadů. Tato mapa zobrazuje $v$ podstatě věrně stav krajiny $v$ polovině 19 . stol. Jen soudobé postupy nebyly zcela dokonalé a tak zde docházelo při zakreslování jednotlivých prvků k posunům až o 50 m různými směry. Tato problematika je mj. popsána v publikaci o historických rybnících [31]. Na základě podkladů II. vojenského mapování anebo Císařských otisků stabilního katastru nelze určit historický výskyt podmáčených lesů, a proto by mohlo dojít ke zkreslení historické rozlohy mokřadů, pokud by se tam v minulosti podmáčený les vyskytoval. Na základě studia archivních mapových podkladů je prokazatelné, že mokřady byly historicky běžnou součástí krajiny. To potvrzuje skutečnost, že Evropa je poznamenána dlouhou historií ovlivňování a využívání krajiny člověkem [32]. Ve střední Evropě byla obrovská plocha mokřadních území přeměněna během několika uplynulých staletí na zemědělskou půdu [33]. Tento trend v ČR potvrzuje analýza změny lokalizace mokřadů v krajině nížin a pahorkatin. Plocha mokřadů před polovinou 19. století tvořila na sledovaném území zhruba 10 \% celkové rozlohy, zatímco v roce 2015 jen 1 \% původní rozlohy mokřadů, což znamená dramatický úbytek mokřadů v krajině. Na místě zmizelých mokřadů je v současnosti nejdominantnějším land use/cover typem orná půda, tvoři 50 \% jejich plochy [34, 35]. Obdobné výsledky vykazovala analýza změny lokalizace mokřadů za posledních 150 let v kantonu Zürich ve Švýcarsku. 


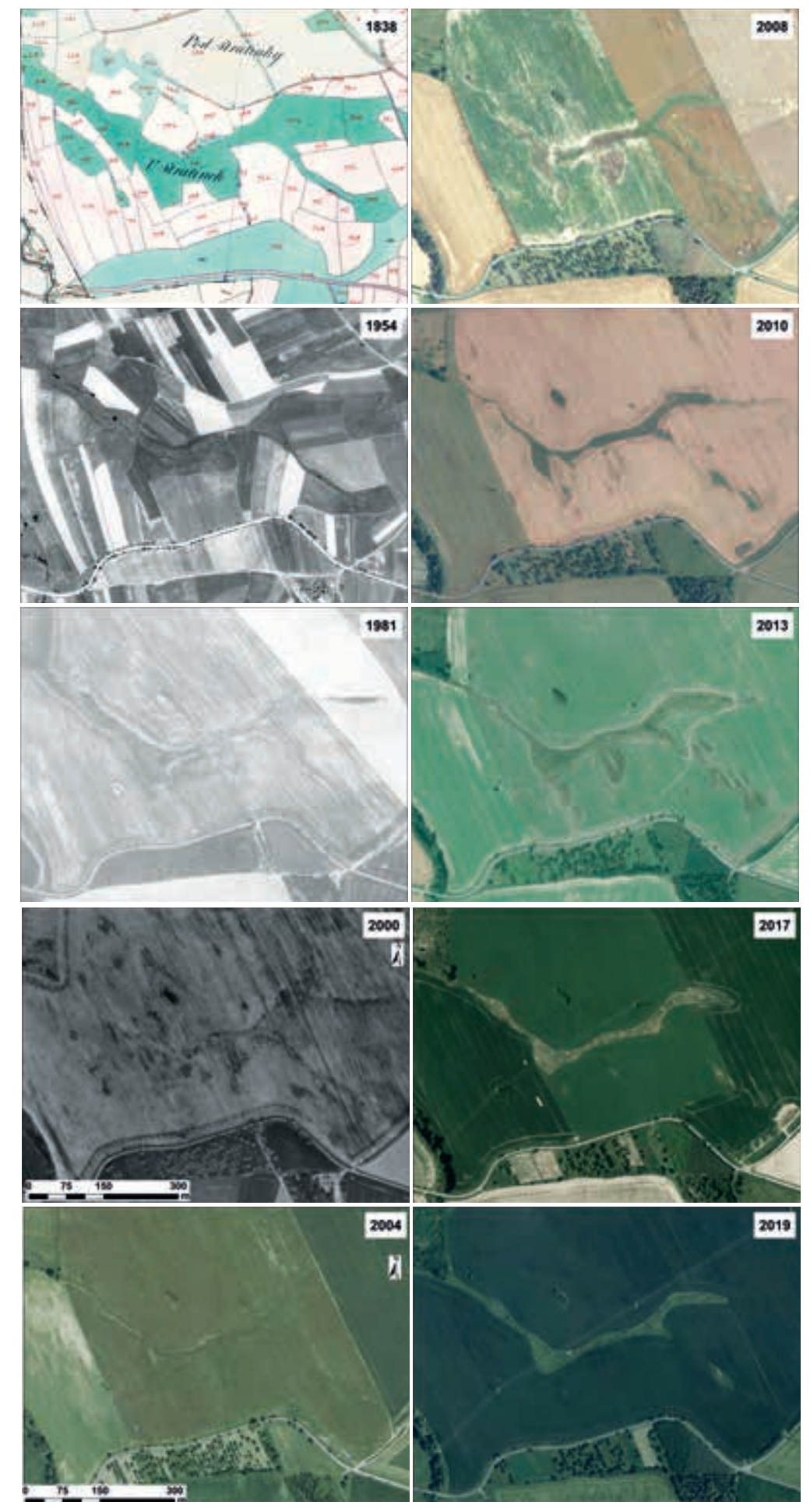

Obr. 8. Historický vývoj a „sukcesní obnova mokřadu v zemědělské krajině v k. ú. Rašovice u Uhlírských Janovic na podkladech Císařských otisků stabilního katastru (1838) [22], ortofotomapě z 50. let 20. stol. [24], archivním leteckém měřickém snímku (1981) [25], archivních ortofotomapách (2000-2017) a současné ortofotomapě (2019) [29] Fig. 8. Historical development and "successional" restoration of wetlands in the agricultural landscape of cadastral area of Rašovice u Uhlírských Janovic in the Imperial Imprints of the Stable Cadastre (1838) [22], orthophotomap from the 1950's [24], historical aerial photography (1981) [25], archival orthophotomaps (2000-2017) and current orthophotomap (2019) [29]
Rozloha mokřadů zde dramaticky poklesla z 8 \% studovaného území v roce 1850 na méně než 1 \% v roce 2000. Rozsáhlé oblasti mokřadních ploch lidé nevnímali jako zdroj výrazné hospodářské prosperity. Možností, jak potenciál území z hlediska hospodaření lépe využít, bylo území odvodnit a intenzivně zemědělsky využívat [33]. Tyto tendence byly $\vee$ menší míře uplatňovány ještě dříve než v 19. a první polovině 20. století, kdy nadešel trend velkoplošných meliorací. Jako př́klad slouží sladkovodní subtropický mokřadní systém Everglades na Floridě o historické rozloze 11000 km². Na počátku 20. století bylo rozsáhlou meliorací vysušeno 65 \% původní plochy, dnes převážně využívané k pěstování cukrové třtiny [36]. Trend zvětšování zemědělských pozemků nebyl spjat jen s érou reálného socialismu, ale probíhal téměř ve všech zemích, kde došlo k intenzivnímu zemědělskému hospodaření, například ve Švédsku [37] nebo Velké Británii [38]. Obdobně napřimování vodních toků neprobíhalo jen v ČR, ale naprríklad i v Německu došlo k napřimování Rýna a dalších vodních toků [39]. Tam se ale jednalo převážně jen o velké vodní toky kvůli splavnění.

Nicméně negativní změny v krajině ČR jsou prokazatelné (k potvrzení si stačí prohlédnout veřejně dostupné archivní a současné mapové podklady), zejména jde o úbytek vodozádržných prvků z krajiny a změnu hospodaření na orné půdě. Způsob hospodaření, započatý v 50. letech 20. století, nejenže nebyl zastaven ale naopak, zdokonalen. Bohužel Ize konstatovat, že v několika ohledech bylo socialistické hospodaření méně devastující, než to nynější. Oba způsoby spojuje používání pesticidů a snaha o odvodnění obhospodařovaných pozemků. Nicméně dříve byly hranice uzavřené, mnoho se toho nedováželo, tak byla nutná tzv. potravinová soběstačnost. Nynější nepř́znivá epidemiologická situace, která v ČR nastala počátkem března 2020 (nyní se postupně zlepšuje, ale existují scénáře, že se situace bude opět zhoršovat) nám ukazuje, že bude nutné potravinovou soběstačnost obnovit. To ale nepůjde se současným systémem vyplácení dotací, kdy je ornice degradována erozí a způsobem hospodaření, což výhledově znamená, že na těchto plochách nepůjde nic smysluplně pěstovat. Pokud by v tomto ohledu ( $v$ tzv. boji proti suchu) byli politici akční už od roku 2014 nebo 2015 stejně jako v boji proti současnému epidemiologickému nebezpečí, jsem toho názoru, že současná situace s vodou v nádržích a se zadržováním vody v krajině by byla mnohem příznivější.

\section{ZÁVĚR}

Mapy stabilního katastru, historické letecké měřické snímky a ortofotomapy jsou velmi přesným zdrojem informací o stavu tehdejší krajiny, zejména pro lokalizaci mokřadů a pro představu o krajině téměř neregulovaných vodních toků. Poznání vývoje mokřadů v krajině nám může pomoci pochopit hlavní hybné síly a tlaky, které měly vliv na jejich změny. Tyto informace Ize pak využít při plánování krajiny s ohledem na obnovu, ochranu a management mokřadů. Tímto způsobem bychom mohli navrátit přirozené mimoprodukční funkce naší krajině. To je důležité obzvlášť $v$ této době, protože jedním z nejtíživějších problémů spojených se současnou klimatickou změnou je velmi malá retenční schopnost běžné krajiny v ČR, tzn. že téměř nezadrží srážkovou vodu. Primárním cílem současné společnosti by proto měla být snaha zpomalit odtok povrchové vody z povodí a zároveň zde zvýšit retenční schopnost krajiny.

\section{Literatura}

[1] MANDER, U KUUSEMETS, $V$, LOHMUS, $K$, and MAURING, T. Efficiency and dimensioning of ripparian buffer zones in agricultural catchmens. Ecological Engineering, 1997, 8 (4), p. 299-324.

[2] LANE, R.R., MASHRIQUI, H.S., KEMP, G.P., DAY, J.W., DAY, J.N., and HAMILTON, A. Potential nitrate removal from a river diversion into a Mississippi delta forested wetland. Ecological Engineering, 2003, 20 (34), p. 237-249.

[3] MAITRE, W., COSANDEY, A.-C., DESAGHER, E., and PARRIAUX, A. Effectiveness of groundwater nitrate removal in a river riparian area: the importance of hydrogeological conditions. Journal of Hydrology, 2003, 278 (1-4), p. 76-93. 

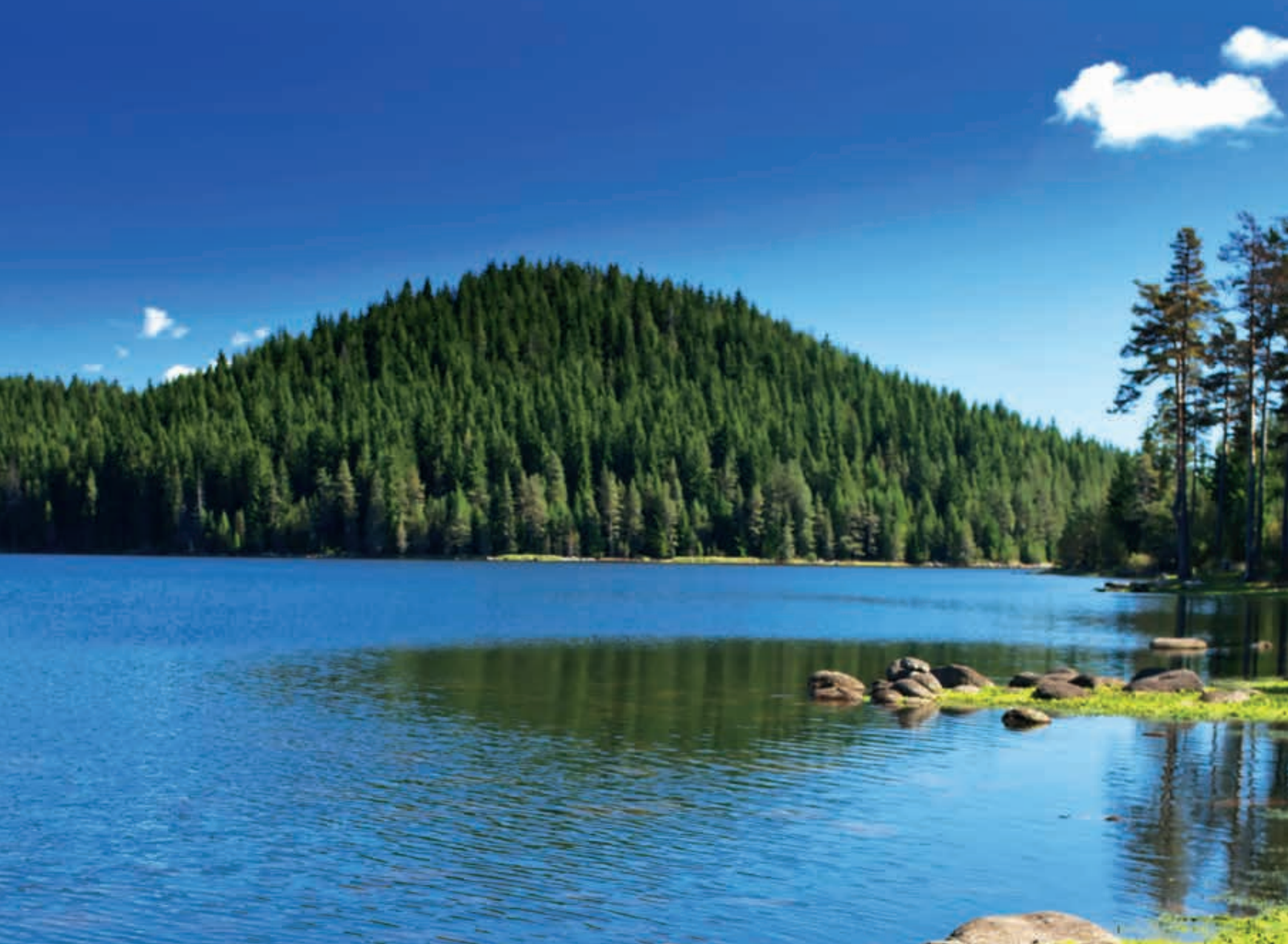

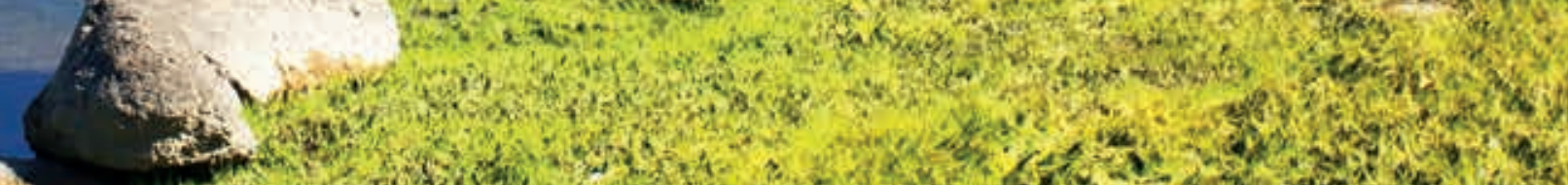

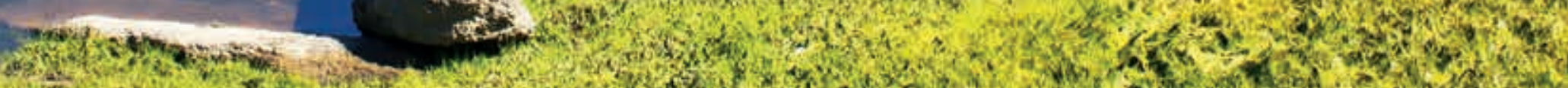

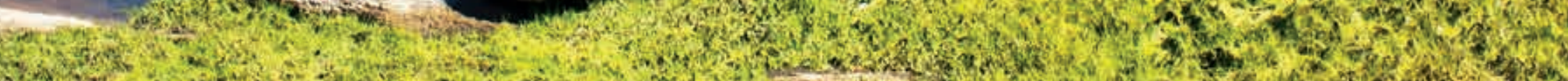

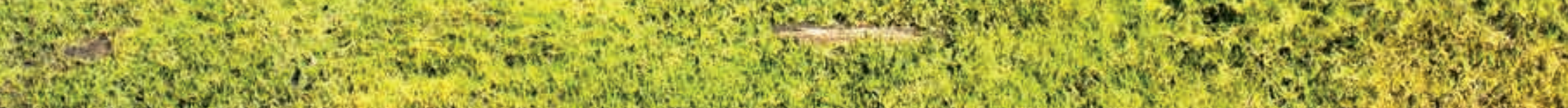

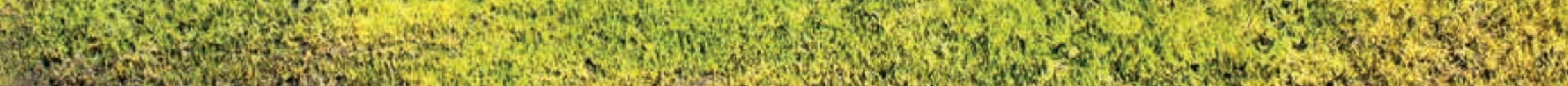

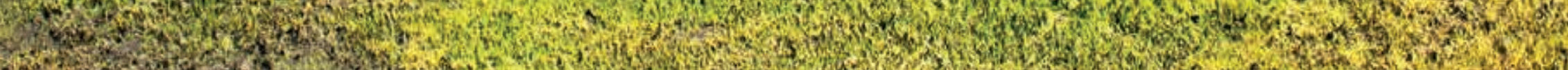
Q60.

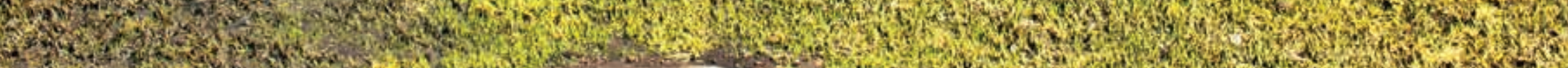
a 
[4] HATTERMANN, F.F., KRYSANOVA, V., and HESSE, C. Modelling wetland processes in regiona applications. Hydrological Science Journal, 2008, 53 (5), p. 1001-1012.

[5] POKORNÝ, J. a EISELTOVÁ, M. Toky energie, vody a látek v krajině. In: Němec, J. (eds.). Krajina a voda Envi Typo pro AOPK, MŽP, MZe ČR, Praha, 1998, s. 55-59.

[6] ARMENTANO, T.V. Drainage of organic soils as factor in the world carbon cycle. Bioscience, 1980 30, p. 825-830.

[7] ARMENTANO, T.V. and VERHOEVEN, J.T.A. Biogeochemical cycles: global. In: Patten, B.C. (ed.) Wetlands and Shallow Continental Water Bodies. SPB Academic Publishing, The Hague, Netherlands, 1991, p. 281-311.

[8] MITSCH, W.J. and GOSSELINK, J.G. Wetlands. John Wiley and Sons, Inc., New York, 5. vydání, 2015, 456 p. ISBN 978-1-118-67682-0.

[9] Sdělení federálního ministerstva zahraničních věcí č. 396/1990. Úmluva o mokřadech majících mezinárodní význam především jako biotopy vodního ptactva a Protokolu o její změně.

[10] LOKOČ, R. a ULČÁK, Z. Percepce krajinných prvků zemědělci - důležitý předpoklad péče o krajinný ráz. In: Klvač, P. (eds.). Člověk, krajina, krajinný ráz. Masarykova Universita, Brno, 2009, s. 61-71.

[11] LIBROVÁ, H. Vlažni a váhaví. Kapitoly o ekologickém luxusu. Doplněk, Brno, 2009, 79 s. ISBN 80-7239-149-6.

[12] SEMOTANOVÁ, E. Historická krajina Česka a co po ní zůstalo. Historický ústav AV ČR, v. v. i. Nakladatelství Academia, Praha, 1. vydání, 2014, 24 s.

[13] JECH, K. Soumrak selského stavu 1945-1960. Sešity Ústavu pro soudobé dějiny AV ČR, 2001, sv. 35, 250 s. ISBN 80-7285-010-5.

[14] JECH, K. Kolektivizace a vyhánění sedláků z půdy. Vyšehrad, s. r. O., Praha, 2008, 336 s. ISBN 978-80-7021-902-7.

[15] LIPSKÝ, Z. Krajinná ekologie pro studenty geografických oborů. Katedra fyzické geografie a geologie Prírodovědecké fakulty University Karlovy, Praha, 1998, 129 s.

[16] KRAVČíK, M. a kol. Voda pre ozdravenie klímy - Nová vodná paradigma. Krupa Print, Žilina, 2007 89 s. ISBN 978-80-969766-5-2.

[17] CÍLEK, V. Pokusme se zachránit to, co zbylo z naší přírody. Eko Dotace, magazín Operačního programu Životni prostředí. Státní fond životního prostředí ČR, Praha, srpen 2010, s. 14-15.

[18] RIPL, W. Management of water cycle and energy flow for ecosystem control: the energytransport-reaction (ETR) model. Ecological Modelling, 1995, 78, p. 61-76.

[19] SKLENIČKA, P. Pronajatá krajina. Centrum pro krajinu, Praha, 1. vydání, 2011, 137 s. ISBN 978-80-87199-01-5

[20] GORE, A. Earth in the Balance. Ecology and the Human Spirit. Houghton Miffin \& Co. Inc. Boston, 1992 407 p. ISBN 978-0395578216.

[21] Mokřady z. s. [online]. [cit. 15. květen 2020]. Dostupné z: http://www.mokrady.wbs.cz

[22] Archivní mapy Ústředního archivu zeměměřictví a katastru [online]. [cit. 15. květen 2020]. Dostupné z: https://archivnimapy.cuzk.cz

[23] Národní geoportál INSPIRE/mapy [online]. [cit. 15. květen 2020]. Dostupné z: https://geoportal. gov.cz/web/guest/map

[24] Národní geoportál INSPIRE/WMS služby [online]. [cit. 15. květen 2020]. Dostupné z: https:// geoportal.gov.cz/web/guest/wms

\section{[25] Mapy.cz [online]. [cit. 18. červen 2020]. Dostupné z: https://mapy.cz/19stoleti}

[26] Maps of Europe/Europe in the XIX. century [online]. [cit. 18. červen 2020]. Dostupné z: https:// mapire.eu/en/map/europe-19century-secondsurvey

[27] Národní archiv leteckých měřických snímků [online]. [cit. 18. červen 2020]. Dostupné z: https:// Ims.cuzk.cz/Ims/Ims_prehl_05.html

[28] Geografická služba AČR/Historické LMS [online]. [cit. 18. červen 2020]. Dostupné z: http://www. mapy.army.cz/historicke-Ims

[29] Geoportál Č́ZZK/Geoprohlížeč [online]. [cit. 15. květen 2020]. Dostupné z: https://geoportal.cuzk. cz/geoprohlizec

[30] Geoportál ČÚZK/Prohližecí služby - WMS [online]. [cit. 15. květen 2020]. Dostupné z: https:// geoportal.cuzk.cz/(S(Icsguqwsq1my1rvbg3qy5suw))/Default.aspx?mode=TextMeta\&side=wms. verejne\&text=WMS.verejne.uvod\&head_tab=sekce-03-gp\&menu=311

[31] PAVELKOVÁ, R., FRAJER, J., NETOPIL, P. a kol. Historickérybníky České republiky: srovnáni současnosti se stavem v 2. polovině 19. století. Praha: Výzkumný ústav vodohospodářský T. G. Masaryka, v. v. i., 2014, 167 s. ISBN 978-80-87402-32-0.

[32] KEDDY, P.A. Wetland ecology - Principles and conservation. United Kingdom, Cambridge University Press, 2. vydání, 2010, 514 p. ISBN 978-0521739672.

[33] GIMMI, U., LACHAT, T., and BÜRGI, M. Reconstructing the collapse of wetland networks in the Swiss lowlands 1850-2000. Landscape Ecology, 2011, 26 (8), p. 1071-1083.

[34] RICHTER, P. a SKALOŠ, J. Sledování změn mokřadů v krajině ní̌in a pahorkatin České republiky 1843-2015. Vodní hospodářství, 2016, 66 (8), s. 14-19.

[35] SKALOŠ, J., RICHTER, P., and KEKEN, Z. Changes and trajectories of wetlands in the lowland landscape of the Czech Republic. Ecological Engineering, 2017, 108, Part B, p. 435-445. ISSN 0925-8574.
[36] VYMAZAL, J. Řasová společenstva mělce zaplavených oblastí severní části floridských Everglades. In: Poulíčková et Kočárková (eds.): Řasy a prostředi, Sborník referátů 39. pracovníkonference Algologickésekce ČBS. Rožmberk nad VItavou, 1999, s. 55-59.

[37] SKÅNES, H. Landscape change and grassland dynamics - Retrospective studies based on aerial photographs and old cadastral maps during 200 years in south Sweden. The Department of Physical Geography Stockholm University. Dissertation series, no 8, papers I-IV, 1996, p. 12-14.

[38] HUNT, R. Rural Britain Then and Now. Octopus Publishing Group Limited, Great Britain, 2004, 208 p. ISBN 978-0-753713-63-1.

[39] BLACKBOURN, D. The Conquest of Nature, Water, Landscape and the Making of Modern Germany. Jonathan Cape, London, 1. vydání, 2006, 497 p. ISBN 978-0-393062-12-0.

\section{Autor}

Ing. Pavel Richter, Ph.D.

凶pavel.richter@vuv.cz

ORCID: 0000-0001-6338-3481

Výzkumný ústav vodohospodářský T. G. Masaryka, v. v. i.

Př́spěvek prošel lektorským řízením.

DOI: $10.46555 /$ VTEI.2020.05.006

\section{WETLANDS ON HISTORICAL MAPS}

\section{RICHTER, P.}

TGM Water Research Institute, p.r.i.

Keywords: archival maps - wetlands - GIS -

water retention in the landscape - agricultural management

This article presents easily accessible archive maps that provide an overview of the historical location of wetlands and they are also suitable for GIS analysis. The main research question is to find out the potential in use of historical maps for the identification of historical or restoring wetlands in the Czech Republic and the subsequent evaluation of driving forces that lead to extinction or restoration of wetlands. This article describes Map II. Military Mapping as the most suitable tool for estimating detection of historical wetlands. The map captures the true state of the landscape in the middle of the $19^{\text {th }}$ century. It was, among other things, a landscape of unregulated watercourses. The Stable Cadastre provides more detailed description of the landscape from this period as the map was designated for mapping the country for tax purposes. It is available only as map sheets that need to be georeferenced for possible GIS use. Other suitable sources for the landscape analysis are historical orthophotomap from the 1950's, historical aerial photographs from 1937-2002 and archival orthophotomaps from 1998-2017. The paper also illustrates the successful wetland restoration on agricultural land on the basis of historical maps. This information can be used in landscape planning with regard on the restoration, protection and management of wetlands that have crucial role in water retention in the landscape. Unfortunately, the wetlands, with the exception of ponds, have almost completely disappeared from the ordinary landscape of the Czech Republic. The article also describes the causes of landscape changes that led to current state. 